\title{
Tumor-associated Antigen 43-9F
}

National Cancer Institute

\section{Source}

National Cancer Institute. Tumor-associated Antigen 43-9F. NCI Thesaurus. Code C96507.

A novel tumor-associated carbohydrate epitope identified by the 43-9F monoclonal antibody and associated with the growth pattern of squamous cell lung carcinomas. Tumor-associated antigen 43-9F is used to differentiate between normal cells and cancer cells in tumor biopsy specimens. 